\title{
Maintenance ERP Risk management for the Service Industry case study: Hajj and Pilgrimage Organization
}

\author{
Nasimkhozouie ${ }^{1}$, YaghoobFarjami ${ }^{2}$,masoudRafighi ${ }^{3}$ \\ 1,2,3 Department of Computer Engineering and IT \\ Qom University \\ Alghadir Boulevard \\ The Old Isfahan Road \\ Qom, Iran Postal Code: 3716146611 \\ n_khozooyi2003@yahoo.com \\ Farjami@gmail.com \\ Masoud_r62@yahoo.com
}

\section{ABSTRACT}

In recent decades, a lot of company across the world have implementedERP systems. Although ERP implementation is a moreexplored issue, But even ERP implementationfinished satisfactorily, success in ERP adoption is notguaranteed. It depends on the effectiveness process in thepost-implementation ERP systems.

There are critical success factors in these projects. In this paper we evaluate critical Risk factor after ERP implementation at Service Industry,especialyHajj and Pilgrimage Organization.

\section{Indexing terms/Keywords}

ERP; Maintenance Risk management; risks factors; impact of risks.

\section{Council for Innovative Research}

Peer Review Research Publishing System

Journal: International Journal of Management \& Information Technology

Vol. 10 No. 2

editorsijmit@gmail.com

www.ijmit.com/ojs 


\section{INTRODUCTION}

Enterprise resource planning (ERP) is business management software-usually a suite of integrated applications-that a company can use to store and manage data from every stage of business, including:

- Product planning, cost and development

- Manufacturing

- Marketing and sales

- Inventory management

- $\quad$ Shipping and payment

ERP provides an integrated real-time view of core business processes, using common databases maintained by a database management system. ERP systems track business resources—cash, raw materials, production capacity-and the status of business commitments: orders, purchase orders, and payroll. The applications that make up the system share data across the various departments (manufacturing, purchasing, sales, accounting, etc.) that entered the data. ERP facilitates information flow between all business functions, and manages connections to outside stakeholders. ${ }^{[1]}$ Enterprise system software is a multi-billion dollar industry that produces components that support a variety of business functions. IT investments have become the largest category of capital expenditure in United Statesbased businesses over the past decade. Though early ERP systems focused on large enterprises, smaller enterprises increasingly use ERP systems. ${ }^{[2]}$

Organizations consider the ERP system a vital organizational tool because it integrates varied organizational systems and facilitates error-free transactions and production. However, ERP system development is different from traditional systems development.[3] ERP systems run on a variety of computer hardware and network configurations, typically using a database as an information repository. ${ }^{[4]}$

\section{ERP project Risk assessment:}

One reason often cited for any software project failure is that managers do not properly assess and manage the Risks involved in their projects. Most project managers perceive risk management processes as extrawork and expense; thus, risk management processes areoften expunged if a project schedule slips. ${ }^{[6]}$.In the past, several ways were proposed in order to improve the success rate of ERP introduction, unfortunately without great effect .The nature of IT project risk is determined by the risk factors and bythestrategicneedfor the project, innovation, repetition of failed experience, etc. Many processes have been developed in recent years to address the need for a more effective riskmanagement, though they are often too general for ERP application, models including PMI 2001, Standards Australia 1999, SAFE methodologyand Risk Diagnosing Methodology . ${ }^{[9]}$ are typical iterative approaches to risk management problems (see Fig. 1)

Main phases are:

1. context analysis;

2. risk identification;

3. risk analysis;

4. risk evaluation;

5. risk treatment;

6. monitoring and review;

7. communication and consulting. 


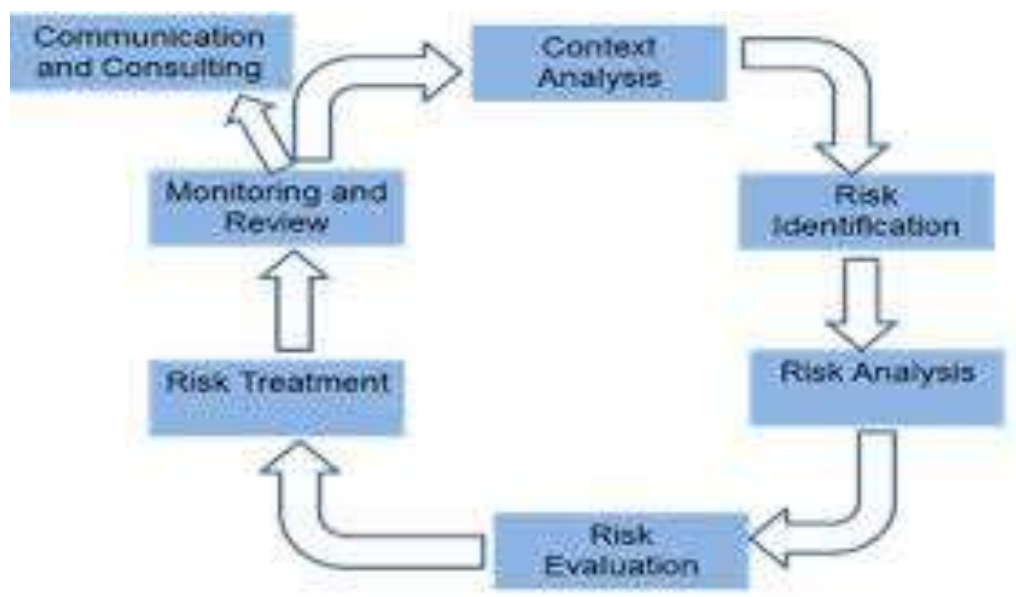

Fig1. Risk management phases

However, ERP projects are interdisciplinary; they affect interdependencies between business processes, software and process reengineering. Critical factors include technological and management aspects, both psychological and sociological. To be effective a risk assessment method should consider several potential aspects (technology, market, financial, operational,organizational, and business) and link them to the project life cycle. This ensures the selection of the most appropriate risk treatment strategy. Risk management strategy consists of two approaches (see Fig. 2).The first aims at reducing risky circumstances, while the second deals with risktreatment after a risk appears. ${ }^{[6]}$

\section{ERP Maintenance Risks:}

Risk management in ERP maintenance is needed according to the high risk, complexity and cost of these projects. An ERP maintenance project is considered successful when it is completed within time and budget and meets ERP users' expectations (Aloini et al.,2007) without damage ERP performance. Poor risk management of ERP maintenance projects often leads to failure, which can affect the system and the project outcome (Wallace et al., 2004a,b). For example, in some cases, ERP-adopting organizations request further requirements for adapting or improving the ERP system functionality.When requirement changes are too continuous, ERP complexityMay get out of control and exponentially extending the ripple effect.

In this situation, the ERP stability will be affected, increasing the initialbudget and the scheduled project time. It consequently causeshuge losses for adopter companies. However, ERP maintenance failurescan beprevented if the ERP maintenance team manages risksprojects properly. This iswhy dentifying, estimating and analyzingrisks projects are essential tasks (ISO/IEC/IEEE, 2006). ${ }^{[5]}$

ERP maintenance risks research is scarce in the literature. In fact, only one ERP post-implementation risks study exists and it presents risks ontology about ERP exploitation (Peng and Nunes, 2009). In spite of this, ERP risks studies represent about $12 \%$ of the ERP research (Botta-Genoulaz et al., 2005). But these focus on the implementation stage. More specifically, a risk factors model

in enterprise systems implementation has been presented (Scott and Vessey, 2002). It is based on the implementation cases of Dow Corning Incorporated and Fox Meyer Drug Corporation. A risk management application has also been created for the modeling,optimal adaptation and implementation of an ERP system (Zafiropoulos et al., 2005). Other studies about ERP implementation

projects even identify risks factors, describe and analyze each onebased on the literature and prioritize them (Sumner, 2000; Huanget al., 2004; Aloini et al., 2007).

However, the literature only brings together three risks in the maintenance phase and these derive from insufficient and inappropriate personnel. But, there are more risk factors that affect successful ERP maintenance projects and ERP maintenance managers must handle them continuously. To support the professionals'work, we have realized a formal study about risks which threaten the ERP maintenance process. To do this, we followed the stages proposed by the risk management international standard ISO/IEC/IEEE, 2006) to perform risk analysis. Fig. 2 shows the steps and results obtained in each stage of theresearch. ${ }^{[1]}$ 


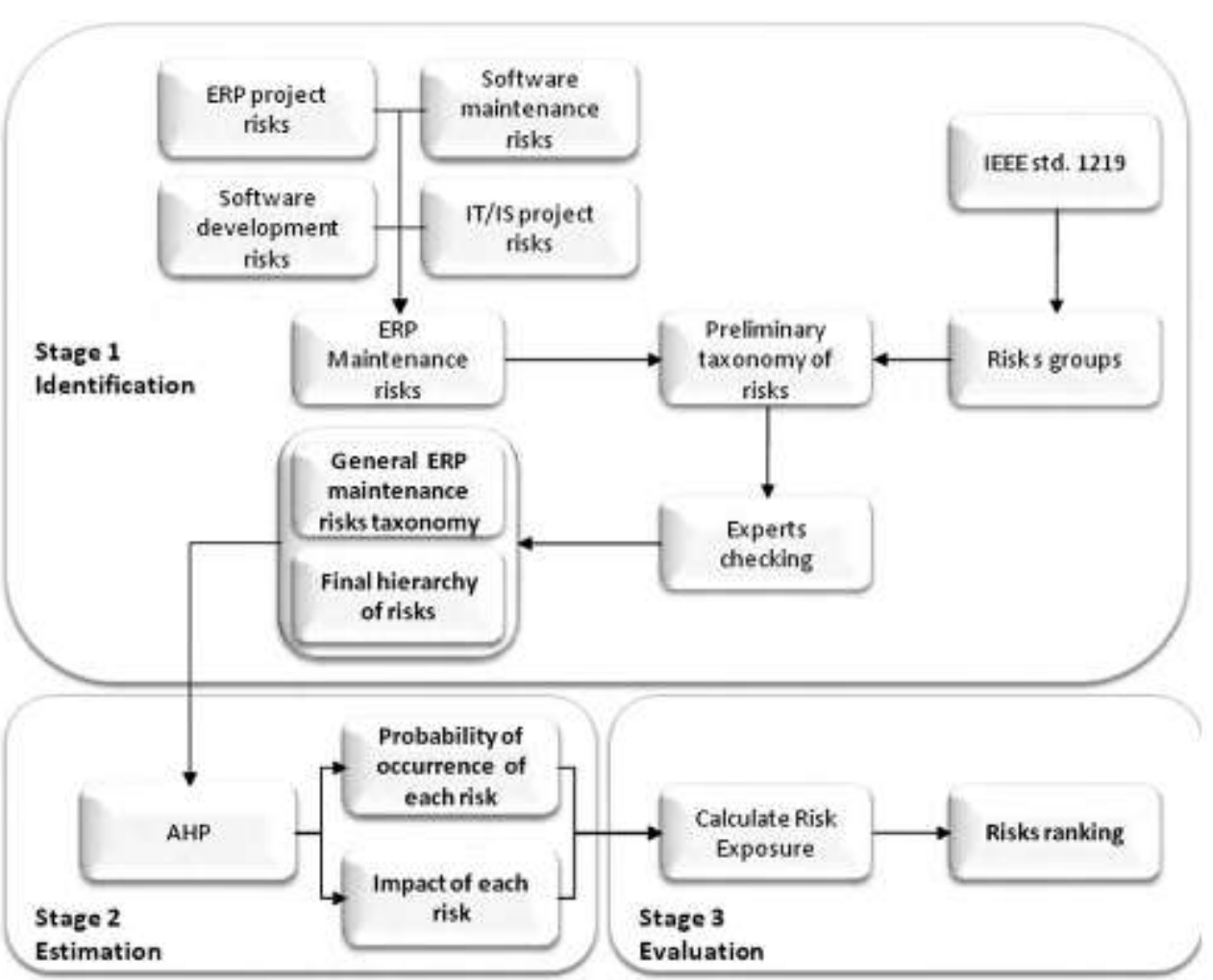

Fig2. Steps and results in the research.

\section{First stage: identifying risks factors in ERP maintenance}

In this stage, the risks that affect the ERP maintenance process are identified and categorized. Different risks could affect the whole ERP maintenance project. The risks taxonomies for IS/IT, software development and maintenance projects are not completely fit to ERP maintenance because the above frameworks are very general and do not take into account the features of ERPsystems. Therefore, it is necessary to create an ERPmaintenance risks taxonomy. ${ }^{[1]}$

\section{Second stage: estimating risks factors in the ERP maintenance process:}

The general risks taxonomy summarizes the threats that affect the ERP maintenance. However, if the maintenance team wants to correctly manage the risk existing in the process, this is not enough. The managers need to know which risks are critical, moderate and marginal. To do so, the maintenance team has to estimate both the probability of occurrence and the impact on the ERP maintenance performance. This is the goal in the risks estimation stage.

To calculate both the probability of occurrence and the impact, we carried out a multicriteria decision-making methodology called AHP.

The AHP methodology was presented by Saaty in the '70s (Saaty,1977, 1980). This technique has been widely used to reflect the importance or weights of the factors associated with priorities (Zahedi, 1986). [1] 


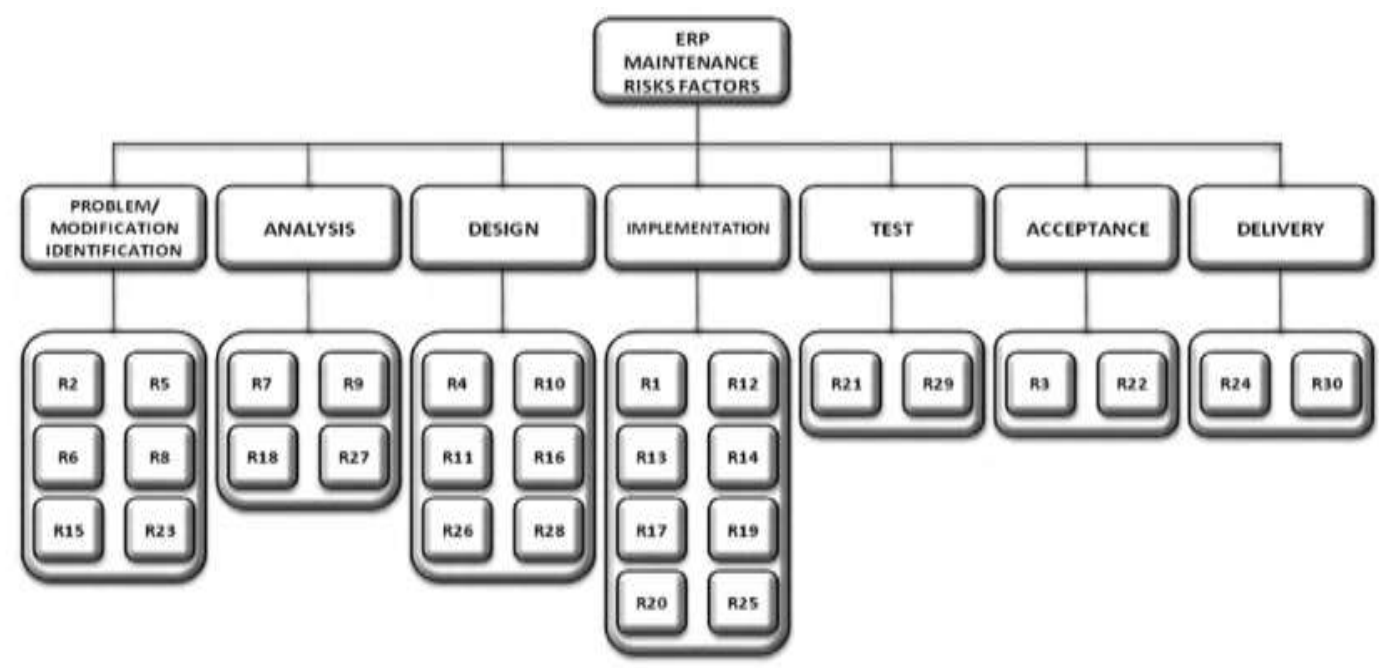

Fig.3 Final hierarchy of Risk

\begin{tabular}{|c|c|c|c|}
\hline RANK & Phase & Risk & Description \\
\hline 1 & Acceptance & R3 & $\begin{array}{c}\text { Users and managers are not involved in the improvement and ERP maintenance. In extreme } \\
\text { cases, user reject the system. }\end{array}$ \\
\hline 2 & Identification & R8 & $\begin{array}{l}\text { Maintenance team does not properly detect which changes have a higher priority. Moreover } \\
\text { the professionals do not order the requests for the maintenance to be performed more } \\
\text { effectively and efficiently. }\end{array}$ \\
\hline 3 & Analysis & R18 & $\begin{array}{l}\text { he magnitude of the project is unknown or poorly defined. Moreover, time and resource } \\
\text { estimated for the implementation of the changes are unrealistic or inaccurate. }\end{array}$ \\
\hline 4 & Implementation & $\mathrm{R} 13$ & $\begin{array}{l}\text { ERP maintenance team members are not involved in the improvement and ERP } \\
\text { maintenance. Another possibility is that the activity does not motivate them. }\end{array}$ \\
\hline 5 & Implementation & $\mathrm{R} 19$ & $\begin{array}{c}\text { Team does not count on methodologies, process and/or standards procedures which support } \\
\text { them in the maintenance. }\end{array}$ \\
\hline 6 & Delivery & $\mathrm{R} 30$ & Poor documentation for support of ERP users. \\
\hline 7 & Identification & $\mathrm{R} 15$ & $\begin{array}{l}\text { The company fails in the selection of the appropriate external parties for the maintenance of } \\
\text { their ERP Another possibility is that the company does not control and/or manage the } \\
\text { cooperation well. }\end{array}$ \\
\hline 8 & Identification & $\mathrm{R} 6$ & $\begin{array}{l}\text { Users, ERP vendors, consultants and/or ERP team maintenance continuously suggest further } \\
\text { modifications. }\end{array}$ \\
\hline 9 & Acceptance & $\mathrm{R} 22$ & Ignored or not explicit definition about the standard of ERP quality. \\
\hline 10 & Regression & $\mathrm{R} 21$ & $\begin{array}{l}\text { Wrong tools, techniques, functions and measurements to test, simulate or evaluate the } \\
\text { modified ERP }\end{array}$ \\
\hline 11 & Identification & $\mathrm{R} 23$ & Users do not want changes in the system \\
\hline 12 & Design & $\mathrm{R} 4$ & $\begin{array}{l}\text { The designers do not fully understand the demands of users, vendors, consultants or the } \\
\text { maintenance team. Also it is possible that they wrongly communicate their requirements. }\end{array}$ \\
\hline 13 & Identification & R5 & Several requests are incompatible. \\
\hline 14 & Implementation & $\mathrm{R} 12$ & Instability and lack of continuation of the personnel team. \\
\hline 15 & Design & $\mathrm{R} 28$ & Specific competence of ERP consultants. \\
\hline 16 & Implementation & $\mathrm{R} 14$ & Maintenance team members are not trained in accordance with the work that they perform. \\
\hline
\end{tabular}




\begin{tabular}{|c|c|c|c|}
\hline 17 & Identification & $\mathrm{R} 2$ & $\begin{array}{c}\text { The environment of the ERP-adopting company changes very much. Constantly emerging } \\
\text { new competitors, products, services, standards, regulations and so on to which it must respond } \\
\text { and adapt. }\end{array}$ \\
\hline 18 & Implementation & $\mathrm{R} 1$ & $\begin{array}{c}\text { The company continuously changes its organizational structure and/or the process and tasks } \\
\text { carried out in the business activity. }\end{array}$ \\
\hline 19 & Analysis & $\mathrm{R} 9$ & ERP maintenance manager lacks necessary knowledge/experience/skills. \\
\hline 20 & Analysis & $\mathrm{R} 7$ & $\begin{array}{l}\text { Difficulty of measuring the impact, safety and security implication, cost and value benefits of } \\
\text { the modification and/or improvement. }\end{array}$ \\
\hline 21 & Design & $\mathrm{R} 11$ & $\begin{array}{c}\text { Team members neither have experience in the technology nor skills and/or necessary } \\
\text { knowledge about ERP systems and their maintenance. }\end{array}$ \\
\hline 22 & Analysis & $\mathrm{R} 27$ & $\begin{array}{c}\text { Existing systems are not well connected or the connections between them are not } \\
\text { documented }\end{array}$ \\
\hline 23 & Regression & $\mathrm{R} 29$ & $\begin{array}{l}\text { Maintenance team does not carry out necessary tests and these will not detect all ERP } \\
\text { mistakes }\end{array}$ \\
\hline 24 & Implementation & $\mathrm{R} 20$ & The milestones are short of details and/or wrongly defined in the implementation plan. \\
\hline 25 & Delivery & $\mathrm{R} 24$ & ERP users are not trained to operate optimally with the system \\
\hline 26 & Implementation & $\mathrm{R} 25$ & $\begin{array}{l}\text { ERP maintenance team carry out excessively complex procedures for programming and } \\
\text { testing the modifications }\end{array}$ \\
\hline 27 & Design & R16 & $\begin{array}{l}\text { The existing documentation on the system and the processes followed in its implementation } \\
\text { and maintenance is poor or incomprehensible. Another possibility is that it is incomplete or null. }\end{array}$ \\
\hline 28 & Design & $\mathrm{R} 10$ & Problems arise continually between team members and/or they do not cooperate sufficiently. \\
\hline 29 & Design & $\mathrm{R} 26$ & Incorrect choice of the ERP modules. \\
\hline 30 & Implementation & $\mathrm{R} 17$ & $\begin{array}{c}\text { Difficulty of measuring the impact, safety and security implication, cost and value benefits of } \\
\text { the modification and/or improvement. }\end{array}$ \\
\hline
\end{tabular}

\section{Table 1. Risk Ranking with description}

\section{Third stage: evaluating risks factors in ERP maintenance:}

In the preceding stage, we estimated the probability of occurrence and the impact on the ERP maintenance performance. However, these elements do not show the importance of each risk.

For example, a risk whose probability of occurrence is very high while its impact is low cannot be considered critical. Thus, the maintenance team has to evaluate all risks. For this reason, the professionals have to rank the risk according to consistent criteria. A risk factor is more or less important depending on its probability of occurrence and its impact on the project, that is, its risks exposure (Boehm, 1991) :[1]

$$
\mathrm{RE} i=\mathrm{PO} i \times \mathrm{li}
$$

Risks management in IT projects is a common practice because it decreasesfailure probability. But, the maintenance managers need to know the importance of all risks identified. 


\begin{tabular}{|c|c|c|c|c|c|}
\hline \multirow[t]{2}{*}{ Priority } & \multicolumn{2}{|r|}{ Risk Description } & \multicolumn{3}{|c|}{ Probability } \\
\hline & Occurrence & Outcome & $\mathbf{P}$ & I & $\mathbf{P} * \mathbf{I}$ \\
\hline 10 & $\begin{array}{c}\text { The lack of clear definitions and } \\
\text { criteria for measuring project } \\
\text { success }\end{array}$ & $\begin{array}{l}\text { Doubton theaccuracy of } \\
\text { theachievements and activities ofthe project,project } \\
\text { failure }\end{array}$ & 10 & 10 & 100 \\
\hline 10 & $\begin{array}{l}\text { Uncertainty in the process and } \\
\text { implementation steps }\end{array}$ & $\begin{array}{l}\text { Refactoringthepurchasedsystem, paralysis by Analysis } \\
\text { remotenessof the project objectives, project failure }\end{array}$ & 10 & 10 & 100 \\
\hline 7 & $\begin{array}{l}\text { The complexity of the proposed } \\
\text { project }\end{array}$ & $\begin{array}{l}\text { Increasing the costof failure to } \\
\text { reachDeadlinefocusonapplyingthe methodologyto } \\
\text { replace theERP implementation }\end{array}$ & 8 & 8 & 64 \\
\hline 7 & Project Scheduling & $\begin{array}{l}\text { Late delivery and degradation achievements and } \\
\text { dissatisfaction with the employer }\end{array}$ & 8 & 8 & 64 \\
\hline 7 & $\begin{array}{l}\text { Instability in the demand for } \\
\text { services and subsystems phase }\end{array}$ & $\begin{array}{l}\text { Disagreement between the parties over time to } \\
\text { determine the scope and impact negatively on schedule }\end{array}$ & 8 & 8 & 64 \\
\hline 5 & The lack of efficient professionals & $\begin{array}{r}\text { Negative impact on the quantity and quality of project } \\
\text { results and schedules }\end{array}$ & 8 & 6 & 48 \\
\hline 3 & $\begin{array}{l}\text { Uncertainly, in preparation for the } \\
\text { implementation of Hajj and } \\
\text { Pilgrimage Organization }\end{array}$ & $\begin{array}{r}\text { Increased cost and delay time separately for the } \\
\text { preparation and delivery }\end{array}$ & 5 & 5 & 25 \\
\hline
\end{tabular}

Table 2.probability of occurrence and impact on ERPprojectofHajj and Pilgrimage Organization

More over, the professionals need to know which risks are critical, moderate or marginal. In this paper we evaluate aspects of critical, moderate and marginal risks of ERP maintenance should be identified, ranked according probability of occurrence and the impact on the ERP maintenance performance.

Table.2 shows the result of this evaluation.(Hajj and Pilgrimage Organization)

On the other hand, this research identifies what the risks affect. However, the professionals also need to know how the risks arise. In this sense, we believe that studies about the ERP maintenance risks dimensions are also necessary.

\section{References}

1. Jose L. Salmeron, Cristina Lopez- A multicriteria approach for risks assessment in ERP maintenance, The Journal of Systems and Software 83 (2010) 1941-1953.

2. Bidgoli, Hossein, (2004). The Internet Encyclopedia, Volume 1, John Wiley \& Sons, Inc. p. 707.

3. Rubina Adam, Paula Kotze, Alta van der Merwe. 2011. Acceptance of enterprise resource planning systems by small manufacturing Enterprises. In: In: Proceedings of the 1tth International Conference on Enterprise Information Systems, Vol.1, edited by Runtong Zhang, José Cordeiro, Xuewei Li, Zhenji Zhang and Juliang Zhang, SciTePress. p. $229-238$

4. SHAUL, L. AND TAUBER, D. 2012. CSFs along ERP life-cycle in SMEs: a field study. Industrial Management \& Data Systems, 112(3), 360-384.

5. Khosrow-Puor, Mehdi. (2006). Emerging Trends and Challenges in Information Technology Management. Idea Group, Inc. p. 865.

6. Risk management in ERP project introduction:Review of the literature, Information \& Management 44 (2007) 547567.

7. Standard Australia, Risk Management, AS/NZS 3360:1999,Standard Australia, Strathfield

8. PMI, A Guide to the Project Management Body of Knowledge (PMBOK Guide), 2000 ed., Project Management Institute Publications, 2001.

9. ESCOM-ENCRESS 98, Project Control for 2000 and Beyond,SAFE methodology, Rome, 1998.

10. J. Keizer, J.I.M. Halman, X. Song, From experience: applying the risk diagnosing methodology, Journal Product Innovation Management 19 (3), 2002, pp. 213-232.

11. Shepherd, J., Klein, E., "The Enterprise Resource Planning Spending Report”, 2006-2007

12. Botta-Genoulaz, V., Millet, P.A., Grabot, B., "A survey on the recent research literature on ERP systems". Computer in Industry, 2005. 